\title{
Lactobacillus Bacteria in Breast Milk
}

\author{
Katarzyna Łubiech *(D) and Magdalena Twarużek (D) \\ Department of Physiology and Toxicology, Faculty of Biological Sciences, Kazimierz Wielki University, \\ Chodkiewicza 30 St., 85-064 Bydgoszcz, Poland; twarmag@ukw.edu.pl \\ * Correspondence: katarzyna.lubiech@ukw.edu.pl; Tel.: +48-668339174
}

Received: 11 November 2020; Accepted: 8 December 2020; Published: 10 December 2020

\begin{abstract}
Breast milk is an optimal food for infants and toddlers. The composition of breast milk adapts to the needs of the developing organism, satisfying nutritional needs at an early stage of growth and development. The results of research to date have shown that breast milk is the best food for a child, containing not only nutrients but also biologically active substances that aid in the optimal, proper growth and development of infants. Among the many components of breast milk, an important element is the probiotic microflora, including bacteria of the genus Lactobacillus spp. These organisms exert a multidirectional, health-promoting effect on the body of children who consume breast milk. The number of lactic acid bacteria, including Lactobacillus, colonizing the breast milk environment and their species diversity varies and depends on many factors, both maternal and environmental. Breast milk, as a recommended food for infants, is an important source of probiotic microflora. The aim of this study was to present the current understanding of probiotic bacteria of the genus Lactobacillus present in breast milk.
\end{abstract}

Keywords: breast milk; probiotic microflora; Lactobacillus spp.; infant nutrition; breastfeeding

\section{Introduction}

Breast milk is a natural food for infants and young children. It satisfies the nutritional needs of a growing and developing infants on many levels. The World Health Organization (WHO) recommends exclusive breastfeeding for the first six months of a child's life and continued breastfeeding while expanding the diet at least until the age of two [1]. The American Academy of Pediatrics (AAP) recommends that infants should be breastfed for the first six months of life with continued breastfeeding while expanding their diet with complementary foods for a year or more [2]. The decision on the duration of breastfeeding while expanding a child's diet considers the individual needs of the mother and child [3]. In 2013-2018, only 41\% of children under 6 months of age were exclusively breastfed worldwide [4]. This value represents the worldwide average. The age of children at weaning in developing countries is significantly higher than that in highly developed countries [5]. The benefits of breastfeeding are taken into account in policies of many countries. The promotion of breastfeeding is recognized as an important element of social policy aimed at reducing the mortality of newborns and young children as well as reducing the financial costs of the treatment of children from this age group. The factor that significantly affects the health of breastfed babies is the microbiota of breast milk.

\section{Materials and Methods}

The methodology to perform this review included the following processes: definition of the aim of the review, a literature search, data collection, evaluation, comparison and analysis.

The literature review included electronic searches of Ebsco, Web of Science, Pubmed and ScienceDirect (November 2000-July 2019). A bibliographic search strategy was conducted to identify studies reporting on the microbiota of breast milk especially Lactobacillus bacteria. The electronic search 
used the following terms: breast milk, breast milk microbiota, breastfeeding, recommendations for breastfeeding, variability in breast milk composition, breast milk ingredients, colostrums, transitional milk, mature milk, probiotic microflora of breast milk, Lactobacillus spp., Bifidobacterium, human milk oligosaccharides, infant nutrition. Reference lists of the previous reviews and relevant studies were examined. Inclusion criteria were papers written in English and Polish published from 1 January 2004 to November 2020. The quality of controlled studies was critically appraised.

\section{Variability in Breast Milk Composition}

Breast milk is perfectly matched to the needs of a growing baby. The composition of breast milk is variable, both in the daily cycle and throughout the entire lactation period [6]. The variability of milk composition is also important due to factors such as the state of health of the mother and breastfed child. Changes in the composition of breast milk ensure the optimal supply of nutrients and biologically active ingredients, depending on current nutritional needs [7]. Breast milk covers not only demand on nutritional ingredients but also provide adequate supply of bioactive nutrients to protect the child. These changes correspondent with current needs of the body [8]. Colostrum appears first after delivery. It is characterized by a very high content of immunoglobulins, primarily secretory immunoglobulin A (sIgA), which support newborn immunity [9]. Immunoglobulins transferred in breast milk are resistant to digestion in the baby's digestive tract and are specifically adapted to antigens that the child is most likely to come into contact with [10]. Colostrum also contains a high concentration of leukocytes and growth factors such as epidermal growth factor [11]. Compared to milk secreted in subsequent stages of lactation, colostrum contains more protein and less fat and lactose. It is a rich source of microand macroelements as well as fat-soluble vitamins [12]. The next stages of lactation are the secretion of transitional milk followed by mature milk. Transitional milk occurs after a period of colostrum secretion that lasts from several days to two weeks after delivery. It still has some of the features of colostrum; however, it is important to increase the amount of milk secreted, which corresponds to the nutritional needs of the newborn. Mature milk is milk secreted from 4-6 weeks after delivery [6].

It is difficult to investigate the effect of the mother's diet on the composition of breast milk. The conducted studies did not show any correlation between the diversity of the mother's diet and differences in the composition of breast milk. This may be related to the compensatory mechanisms responsible for maintaining the relative stability of the macronutrient composition in relation to differences in the diet of breastfeeding women. However, there is a relationship between the macronutrient content in human milk and the nutritional value of maternal daily consumption [13]. Although the variability in the maternal diet has no effect on the quantitative fat content of breast milk, an effect on the qualitative composition of fatty acids is observed [14]. Fatty acids act as immunomodulators in breastfed babies [15]. Studies in animal models have shown that they can influence the composition of the intestinal microflora in early life [16]. There is a relationship between the composition of the mother's body and the composition of the macronutrients of breast milk. There is a positive relationship between the fat content of the mother's body and the protein content of breast milk [14].

\section{Probiotic Microflora of Breast Milk}

Breast milk is an extremely important source of biologically valuable ingredients, including the probiotic microbiota [17-20]. The colonization of the organism begins in prenatal life. Many species of bacteria have been identified in neonatal meconium, placenta, and amniotic fluid. The composition of the fetal microbiota may be influenced by maternal factors such as maternal conditions, eating habits, and body weight [21]. Prenatal stress has also been shown to influence the differentiation of the child's microbiome [22]. It has been investigated that the composition of the microbiome of the first-pass meconium is influenced by maternal factors during pregnancy [23]. The digestive tract of growing children is colonized by microorganisms that largely depend on the type of delivery [24]. The colonization of the child's body continues during their passage through the mother's vaginal canal, 
skin-to-skin contact, and breastfeeding. In addition, some bacterial strains come from the hospital environment. In the case of delivery via cesarean section, colonization with undesirable hospital microorganisms is dominant. Breast milk is one of the main factors that shapes the microbiological balance of the newborn's digestive tract $[25,26]$. This is due to the high content of probiotic bacteria [27]. Human milk contains a wide spectrum of bacteria such as Staphylococci, Streptococci, Corynebacteria, lactic acid bacteria, Propionibacteria, and Bifidobacteria [28]. Among these populations, probiotic bacteria are present in an amount of $10^{1}-10^{7}$ colony forming units per $\mathrm{mL}$ [29].

There are fewer cases of infection among breastfed children, which may be associated with differences in the composition of the intestinal microbiota [30]. The correct composition of the intestinal microbiota affects the proper functioning of the entire body and prevents the development of many diseases. The benefits of microbial homeostasis are both short- and long-term. An adequate supply of probiotic microorganisms with food supports the proper formation of the microbiological profile and provides maximum benefits from microbiological homeostasis in the gastrointestinal tract [31]. Probiotic microorganisms affect the maturation and development of the immune system [32,33]. In addition, they have trophic and metabolic effects. They affect the integrity of the gastrointestinal mucosa and the production of sIgA antibodies. They also contribute to the formation of the immune system associated with the gastrointestinal mucosa, gut-associated lymphoid tissue (GALT) [34]. The probiotic microbiota is also important for preventing gastrointestinal infections by eliminating or reducing the number of pathogenic microflora. Mechanisms that drive this effect include antimicrobial properties, altering intestinal conditions, and competing for intestinal epithelial adhesion sites and nutrients with pathogens [35]. The stimulation of intestinal mucus production and mobilization of the immune system provides additional protection against intestinal colonization by pathogens [36]. Studies have shown that bacteria present in breast milk may play a role in defense against the pathogenic microorganism Staphylococcus aureus [37]. The ability to inhibit the growth of pathogenic bacteria may be due to competitive exclusion and the production of antimicrobial compounds such as bacteriocins, organic acids or hydrogen peroxide [38]. The probiotic microflora also reduces the risk of diabetes, obesity, hypertension and hypercholesterolemia [2]. The microbiological balance of the digestive tract in infants reduces the risk of necrotizing enterocolitis (NEC). NEC is a disease that often requires surgical treatment. The cause of this disease is an immaturity gastrointestinal tract, blood supply disorders, artificial nutrition and disorders of the composition of the intestinal microflora. An efficiently functioning intestinal microflora reduces the risk of diseases such as recurrent streptococcal tonsillitis in children, otitis media, ulcerative colitis, urinary tract and gastrointestinal infections, respiratory tract infections and diarrhea [37]. Maintaining the microbial balance is also important for the proper functioning of the digestive tract. The role of commensal microorganisms involves the ability to break down toxins and carcinogens, synthesis of trace substances, fermentation of undigested food ingredients, and participation in the process electrolyte and mineral salt absorption [34].

In pre-term infants, differences in the composition of the gut microbiota are observed compared to full-term infants. Each stage of pregnancy is important for the proper development of the body. Premature birth results in disturbances in the formation of the optimal composition of the intestinal microbiota, increasing the predisposition to develop disorders such as necrotizing enterocolitis (NEC). The composition of the microbiota of premature babies is dominated by Enterobacteriaceae and Clostridium. In term infants Bifidobacterium, Lactobacillus and Streptococcus dominate. Factors disturbing the proper colonization of the intestines include: low birth weight, physiological immaturity, the use of antibiotics and prolonged hospitalization [39]. Breastfeeding is often difficult in cases of pre-term labor. It often takes a great deal of effort and time for the mother to develop sufficient lactation to cover the baby's nutritional needs. For premature infants, breast milk has therapeutic value. Through the bioactive factors it affects the maturation of the immune system, supports the formation of a proper intestinal microbiome, and protects against infections [40]. Human milk oligosaccharides (HMO) concentration in breast milk of mothers who gave birth prematurely is much higher $(2.6 \mathrm{~g} / \mathrm{dL})$ compared to the milk of mothers who gave birth on time $(0.5-1 \mathrm{~g} / \mathrm{dL})$. It may be an adaptation of milk 
composition to the needs of premature babies, protecting them against infectious diseases to which they are exposed [41]. When breastfeeding is not possible, it is recommended to introduce breast milk derived from donors. For safety reasons, breast milk is pasteurized. This procedure reduces the content of valuable bioactive ingredients. It has been shown that the inoculation of pasteurized donor milk with the addition of mother's breast milk has a positive effect on the reconstruction of the breast milk microbiota [42].

Breast milk contains not only probiotic microorganisms that affect the composition of the intestinal microbiota but also factors supporting its growth. These factors are oligosaccharides that act as prebiotics [43]. HMOs include more than 200 structurally distinct oligosaccharides [44]. HMOs are prebiotics that support the development of probiotic microflora. Oligosaccharides are not digested in the intestines, which makes them an ideal food for microorganisms, enabling their growth [45]. Qualitative HMO composition varies between women. One of the beneficial effects of HMOs in the digestive tract is their ability to block the binding of pathogens to intestinal epithelial cells. Another anti-pathogenic effect is supporting a population of probiotic intestinal bacteria such as Bifidobacteria. HMOs affect the epithelial cells of the intestinal mucosa by modulating apoptosis, proliferation and differentiation [46]. Human milk oligosaccharides have the ability to modulate the immune system. Disturbances of the homeostasis between the host immune system and microbiota modulates inflammation. Immune-suppressive mechanisms are indispensable for intestinal homeostasis. Due to the diversity of these components in human milk, their effect on the infant's immune system may differ from mother to infant [47].

Breast milk contains non-protein nitrogen in the form of, among other nucleotides, creatinine, free amino acids and peptides. Nucleotides have a beneficial effect on the development of the intestinal microbiota.

The quantity and qualitative composition of the probiotic microflora in breast milk is variable. Factors that determine the content of probiotic bacteria in breast milk can generally be divided into environmental factors and maternal factors. These include the diet during pregnancy and lactation, the mother's state of health, antibiotic therapy, environmental conditions in which a woman lives, etc. These factors can significantly contribute to a significant diversity in the microbiological composition of milk [48,49]. Research conducted in mice (Reven 2015) showed a relationship between the supply of probiotics to pregnant and lactating mice and the increased detection of the mammary gland microbiota [50]. This confirms that the individual variability of the microbiota composition depends on additional factors, such as probiotic supplementation. A child that consumes approximately $800 \mathrm{~mL}$ of breast milk a day absorbs $8 \times 10^{4}-8 \times 10^{6}$ commensal bacteria [37]. The digestive tract of breastfed children contains a narrow spectrum of Gram-positive bacteria [51]. Only the expansion of the child's diet to include solid foods significantly increases the species diversity of the intestinal microflora $[26,52]$. In the breast milk of healthy women, there are commensal bacteria such as Lactobacilli, Lactococci, Enterococci and Leuconostoc spp. Among Lactobacilli present in breast milk, the following have been identified: Lactobacillus gasseri, Lactobacillus rhamnosus, Lactobacillus plantarum, Lactobacillus fermentum and Enterococcus faecium. Lactic acid bacteria and Bifidobacterium make up to $85 \%$ of the entire bacterial population of the intestinal microflora. The human digestive tract contains a complex population of microorganisms. The composition of the microbiota stabilizes between 3 and 5 years of age [31].

\section{Shaping the Child's Microbiota}

During childbirth, children come into contact with microorganisms that are then involved in shaping the microbiota of their body. The formation of the microbiological profile of the child's digestive tract is shaped by many factors, the most important of which are the type of delivery, feeding method and environmental factors [53]. This process begins during pregnancy. Scientific reports have confirmed that the amniotic fluid is not microbiologically sterile and that the fetus is already in contact with microorganisms at this stage [54,55]. Childbirth is essential for the colonization of a child's body by microbes. Natural childbirth is the most beneficial. In this case, the acquisition of the microbiota takes 
place during the passage through the mother's genital tract [56]. In addition, the mother's body is stressed during labor, which causes the mobilization and migration of microorganisms in the woman's body. The situation is different when a cesarean section is performed. The child is not able to acquire microbiota from the mother's genital tract, and the first microorganisms that he contacts after delivery are the adverse hospital microflora. A Cesarean section, although needed in many cases and saving the life of a newborn, unfortunately does not provide him with an optimal start. The adverse conditions of children who are born via cesarean section are common knowledge, various actions are undertaken to ameliorate them. One method is to place sterile swabs in the genital tract of a woman giving birth by cesarean section. After delivery, these swabs are used to wipe the newborn. This action aims to colonize the child's body with the natural microbiota of the mother, even when natural delivery is not possible [57].

Even children who were born via cesarean section have the opportunity to significantly improve the probiotic microflora profile by consuming mother's milk. Exclusive breastfeeding is essential in this case. The microbiological profile of the gastrointestinal tract of children exclusively fed with breast milk is different from children fed with formula or in a mixed manner. Lactobacilli counts are higher in breastfed infants than formula-fed infants [58]. Changes that occur after the administration of formula may be somewhat offset by subsequent breastfeeding, but some differences in the species diversity of microorganisms that inhabit the baby's digestive tract remain that cannot be changed. That is why breastfeeding immediately after delivery is so important. The microbiological profile of the digestive tract of newborns who use formula promotes the development of allergic reactions, autoimmune diseases, and many other disease entities, including civilization diseases. Studies of breastfed children have shown that they have a lower susceptibility to NEC, a disease that is extremely dangerous in the first stage of life, especially among premature babies. The microbiota of breast milk affects the microbiota of the child's digestive tract, and thus is an important factor in maintaining body homeostasis, preventing many disease entities in both the short and long term [59]. The conducted studies indicate the possibility of influencing the composition of breast milk by taking probiotics by pregnant and lactating women. A relationship was observed between maternal supplementation with multi-component probiotic preparations and IL6 mean values in colostrum and between IL10 and TGF- $\beta 1$ mean values in mature breast milk. Changes in the composition of breast milk resulted in a reduced incidence of infantile colic and regurgitation in infants [60]. Studies on the effect of probiotic supplementation by pregnant and lactating women showed a relationship between the amount of Lactobacilli and Bifidobacteria in the colostrum and mature milk of mothers receiving probiotic preparation with vaginal delivery compared to mothers receiving placebo. There was no difference in women who had a caesarean section [61]. Also, research conducted by Abrahamsson et al. have shown the ability to transfer the Lactobacillus bacteria in breast milk after oral supplementation of women in the final stages of pregnancy [62].

\section{The Origin of Bacteria in Breast Milk}

The origin of bacteria in breast milk is not entirely clear. One of the sources of microorganisms found in breast milk is the digestive tract of the mother-the bacterial entero-mammary pathway $[17,28,63]$. The migration of microorganisms in the gastrointestinal tract occurs via the mesenteric lymph nodes and then dendritic cells [64]. Dendritic cells (DCs) can penetrate the intestinal epithelium and thus can take up bacteria from inside the intestines [64]. DCs can take up intestinal-derived bacteria without disrupting the integrity of the intestinal epithelial barrier. The opening of tight junctions between intestinal epithelial cells is possible due to the expression of tightly bound proteins [17]. These proteins include occludin, claudin 1 and Junctional Adhesion Molecule (JAM). They can create junction-like structures with surrounding epithelial cells [65]. The transport mechanism of non-pathogenic microorganisms also applies to CD18+ cells, including macrophages. After penetrating DCs or macrophages, the intestinal bacteria can move to other places, including the mammary gland during the lactation period [17]. Microorganisms pass further into the lumen of secretory vesicles in 
the mammary gland, and together with milk, enter the baby's body, where they participate in the formation of the intestinal microbiota of the newborn. There is also a theory that microorganisms enter breast milk through the skin of the nipple. Bacteria can exist on the surface of the nipple and in the mammary duct system in the form of a biofilm [26] and provide a source of microorganisms for the suckling child [66-68]. Each of these sources plays a role in shaping the specific microbiota of breast milk. A study showed that the milk of women who directly breastfeed children has a greater proportion of bacteria of the phylum Actinobacteria and family Veillonellaceae compared to pumped breast milk [69]. This confirms that some of the microorganisms in the breast milk environment come from the mouth of a breastfeeding child. The newborn's oral cavity is inhabited by microorganisms originating from the female reproductive tract during delivery. It was proven that children fed pumped breast milk achieved a higher body mass index later in life than children who were fed breast milk directly from the breast [70,71]. This may be due to the lack of microorganisms from the child's mouth in the microbiota of pumped breast milk. In addition, the method of collecting milk and its storage can significantly change components that have important effects on the child's health. Breastfeeding directly from the mother's breast may affect the regulation of the baby's food intake.

It has been suggested that neonates can acquire vaginal strains of probiotic microorganisms during labor and then transmit these bacteria to the breast during breastfeeding [68]. Research has indicated that the mother's vaginal microflora has a small effect on the qualitative composition of the microbiota of mother's milk and infant feces. However, a correlation was found between the composition of the milk microbiota and the infant's feces, which indicates a strong role of breastfeeding in the formation of the intestinal microbiome [25].

Studies have shown the presence of DNA and cellular structures of intestinal bacteria in the placenta, amniotic fluid and fetal membranes $[54,55,66]$. This means that the baby is in an environment where microorganisms are present even before delivery, and these may also colonize the baby's body. Scientists have concluded that all these mechanisms contribute to the colonization of the mammary gland with probiotic microorganisms.

\section{Bacteria of the Genus Lactobacillus spp.}

There are more than 200 strains of bacteria in breast milk, of which the most important are Lactobacilli, Bacteroides and Bifidobacterium. Lactobacillus bacteria (belonging to lactic acid bacteria) have the ability to break down lactose and other simple sugars into lactic acid [72]. The methodology of research on the presence of Lactobacillus bacteria in breast milk includes breeding studies on the Man, Rogosa, and Sharpe (MRS) agar medium. Some researchers use MRS supplemented with 1-cysteine ( $0.5 \mathrm{~g} / \mathrm{L}$ ) (MRS-Cys) Incubation is usually carried out in the conditions of: $37^{\circ} \mathrm{C}$ for $48-72 \mathrm{~h}$. Identification at the species level can be performed by mass spectrometry MALDI (Matrix-assisted laser desorption/ionization) or by polymerase chain reaction (PCR) sequencing.

The microbiological profile of breast milk varies among individuals, both in quality and quantity. Some strains are constantly present in breast milk, while others such as Lactobacillus are characterized by variability and are not present in milk samples from every woman [73]. For example, Sinkiewicz and Ljunggren isolated L. reuteri from the milk of only approximately $15 \%$ of breastfeeding women [74]. Soto et al. detected the presence of Lactobacillus bacteria in $40.91 \%$ of tested samples. L. casei, L.fermentum, L. gasseri, L. gastricus, L. plantarum, L. reuteri, L. rhamnosus, L. salivarius, L. vaginalis, and L. rhamnosus can be isolated from breast milk [25]. L. salivarius, L. fermentum and L. gasseri are dominant in this group. Tests showed a lower frequency of bacteria of the genus Lactobacillus in milk samples from women who underwent antibiotic therapy or cesarean section. A relationship was also found between the reduced detection of L. salivarius and the use of anesthesia during delivery [75]. The spectrum of Lactobacillus groups is narrow in breast milk and infant feces. The composition of bacterial strains is specific and includes only a small number of Lactobacilli strains [25].

Human milk is an important source of lactic acid bacteria in shaping the intestinal microflora of breast-fed infants. A study by Matsumiya et al. showed that less than one-fourth of newborns with 
vaginal delivery were acquired by vaginally derived lactic acid bacteria. After one month, these bacteria were replaced with lactic acid bacteria from breast milk [76]. Lactobacillus composition is similar within a mother-child pair and contains small number of Lactobacilli strains [37]. Studies indicate that lactic acid bacteria in the gastrointestinal tract are found only in $74 \%$ of infants in the first months of life. Ahrné et al. isolated one strain of lactic acid bacteria from $37 \%$ of infants, $26 \%$ had two strains, and $11 \%$ had three or more strains. In this study, most babies were fed breast milk. Lactobacillus bacteria were more often isolated from the stools of infants receiving breast-milk than from weaned infants [77]. Research by Martin et al. indicate the presence of the same specific Lactobacillus strains in breast milk and breastfed infant faeces [78].

Compared to that in formula-fed infants, the intestinal microbiota of breastfed infants is richer in Lactobacilli and Bifidobacteria [58]. At the same time, a reduced number of Veillonellaceae, Enterococcaceae, Streptococcaceae and Lachnospiraceae is observed [79]. Many studies confirm the health-promoting effects of Lactobacillus bacteria derived from breast milk on the baby's body. Studies have shown the effectiveness of disease prevention by L. reuteri, L. rhamnosus and many others [80,81]. The probiotic potential of Lactobacillus bacteria isolated from breast milk is similar to that of strains used in probiotic products used in medicine [82,83]. A beneficial effect of Lactobacillus bacteria in the prevention and treatment of mastitis in women was also found [84]. Lactobacillus strains isolated from breast milk may be included in the treatment of mastitis. Their safety is appreciated due to their natural origin, anti-infectious and immunomodulatory properties [85].

Studies have shown that the oral intake of Lactobacillus bacteria, previously isolated from breast milk, effectively reduces mastitis during lactation caused by Staphylococcus aureus. This could be due to the ability of Lactobacilli to adhere to the surface of epithelial cells, inhibit adhering pathogens and promote mucin production [86].

The oral intake of Lactobacillus strains by breastfeeding women results in the presence of these strains in human milk samples and their isolation from the feces of breastfed children. Various Lactobacillus strains differentially modulate the immune system, e.g., L. fermentum has an immunomodulatory effect, while L. salivarius has an anti-inflammatory effect [87].

Table 1 presents research on Lactobacillus bacteria in breast milk and important key results.

Table 1. Research on Lactobacillus in breast milk and important key results.

\begin{tabular}{|c|c|}
\hline Results: & Source: \\
\hline $\begin{array}{l}\text { Lactobacilli isolated from } 40.91 \% \text { samples of breast milk } \\
\text { Bifidobacteria isolated from } 10.61 \% \text { samples of breast milk } \\
\text { Isolated species: } \\
\text { - L. salivarius isolated from } 13.64 \% \text { of samples } \\
\text { - L. fermentum isolated from } 10.61 \% \text { of samples } \\
\text { - L. gasseri isolated from } 9.09 \% \text { of samples } \\
\text { - L. reuteri isolated from } 11.88 \% \text { samples } \\
\text { - L. plantarum isolated from } 10.63 \% \text { samples } \\
\text { - L. rhamnosus isolated from } 8.13 \% \text { samples } \\
\text { - L. casei isolated from } 4.38 \% \text { samples }\end{array}$ & Soto et al. 2014 [75] \\
\hline $\begin{array}{l}\text { L. reuteri isolated from the breast milk of only approximately } 15 \% \text { of } \\
\text { breastfeeding women }\end{array}$ & Sinkiewicz et al. 2008 [74] \\
\hline $\begin{array}{l}\text { Lactobacilli counts higher in breastfed infants gut microbiota than } \\
\text { formula-fed infants }\end{array}$ & $\begin{array}{l}\text { Rinne et al. } 2005 \text { [58] } \\
\text { Ahrné et al. } 2005 \text { [77] }\end{array}$ \\
\hline $\begin{array}{l}\text { A positive relationship between the amount of Lactobacilli and Bifidobacteria in } \\
\text { the colostrum and mature milk of mothers receiving probiotic preparation with } \\
\text { vaginal delivery compared to mothers receiving placebo, } \\
\text { no difference in women who had a caesarean section }\end{array}$ & $\begin{array}{l}\text { Mastromarino et al. } 2015 \\
{[61]}\end{array}$ \\
\hline
\end{tabular}


Table 1. Cont.

\begin{tabular}{cc}
\hline Results: & Source: \\
\hline $\begin{array}{c}\text { Ability to transfer the Lactobacillus bacteria in breast milk after oral } \\
\text { supplementation of women in the final stages of pregnancy }\end{array}$ & $\begin{array}{c}\text { Abrahamsson et al. 2009 } \\
\text { Individual variability of Lactobacillus strains in breast milk }\end{array}$ \\
\hline $\begin{array}{c}\text { Lactobacillus composition is similar within a mother-child pair and contains } \\
\text { small number of Lactobacilli strains }\end{array}$ & $\begin{array}{c}\text { Heikkilä et al. 2003 [37] } \\
\text { Martín et al. 2012 [78] }\end{array}$ \\
\hline $\begin{array}{c}\text { Lactobacillus strains isolated from breast milk may be included in the treatment } \\
\text { of mastitis }\end{array}$ & Arroyo et al. 2010 [85] \\
\hline $\begin{array}{c}\text { Lactobacillus strains differentially modulate the immune system, e.g., L. } \\
\text { fermentum has an immunomodulatory effect, while L. salivarius has an } \\
\text { anti-inflammatory effect }\end{array}$ & Díaz-Ropero et al. 2007 [87] \\
\hline
\end{tabular}

\section{Summary and Conclusions}

Probiotic bacteria are an important element that contributes to the proper development of children. Many studies have reported the beneficial effect of probiotic bacteria, including Lactobacillus bacteria, in breast milk on the formation of the infant's intestinal microbiome. It is important to understand factors that may influence the shaping of the microbiological profile of both breast milk and the child's digestive tract and their mutual correlations. As probiotic bacteria in the diet has great benefits, it is important to ensure the optimal quality of food consumed by children, including breast milk as the first recommended food for children from birth. Research has indicated that various factors influence the composition of milk, including the qualitative composition of the human milk microbiome. Species diversity is influenced by external factors, but it is also regulated by endogenous factors of the female body. Many factors can affect the human milk microbiota. These factors can generally be divided into those derived from the environment and maternal factors. These include the lactation period, maternal dietary habits and nutritional status as well as mode of delivery, gestational age. Also, external factors like geographical location, and the use of antibiotics or other medicines can have an influence on the milk microbiota composition [88]. Lactobacillus bacteria are less often isolated from breast milk samples of women who had received antibiotherapy during pregnancy or lactation [75]. Dietary habits, the environment and social conditions may contribute to a significant differentiation of the composition of breast milk microbiota [49]. The conducted studies indicate a lower species diversity of human milk microbiota from women who underwent cesarean section. Higher levels of Staphylococcus spp. and lower levels of Enterococcus spp. are detected in breast milk derived from mothers who had C-section compared with vaginal deliveries. The Bifidobacterium group is detected more frequently in vaginal than in C-section deliveries. This difference is not statistically significant [89]. Detection of Lactobacilli is higher in breast milk of women who have vaginally delivered than women who have delivered by caesarean section [75].

The mother's health and medical conditions may affect the composition of the milk microflora. For example, the milk of allergic mothers contains a lower number of Bifidobacterium longum compared to non-allergic mothers [90]. Mastitis is another factor influencing the composition of breast milk. Breast milk of women suffering from mastitis is dominated by Staphylococcus aureus [91]. Breast milk of women with celiac disease has reduced levels of Bacteroides spp. and Bifidobacterium spp. [92]. Indicate the influence of acquired immune deficiency syndrome (AIDS) on the breast milk composition. Breast milk samples derived from HIV-positive women has higher bacterial diversity and higher prevalence of Lactobacillus spp. than those of non-HIV-positive women [93].

The mother's body weight may also influence the composition of the breast milk microbiota. The number of Bifidobacterium bacteria was lower, while the number of Staphylococcus bacteria was higher in the breast milk of overweight mothers than in normal-weight mothers [94]. 
Probiotic bacteria of the genus Lactobacillus show multidirectional pro-health effects on the human body. Their presence in breast milk seems to be extremely valuable in shaping the correct microbiota of breastfed infants. It is particularly important to provide probiotic strains to premature babies. The results of the research indicate that strains of bacteria of the genus Lactobacillus are isolated from breast milk samples only in some of the breastfeeding women and their species differentiation in the breast milk of individual women is very narrow. Typically, one strain belonging to the genus Lactobacillus is isolated. It is of great importance to recognize the factors that may modulate the quantitative and qualitative composition of the breast milk microbiota.

Author Contributions: Conceptualization, K.Ł. and M.T.; investigation, K.Ł.; writing—original draft preparation, K.Ł.; writing-review and editing, K.Ł. and M.T.; supervision, M.T.; funding acquisition, M.T. All authors have read and agreed to the published version of the manuscript.

Funding: This study was supported by the Polish Minister of Science and Higher Education, under the program "Regional Initiative of Excellence" from 2019 to 2022 (grant no. 008/RID/2018/19).

Conflicts of Interest: The authors declare no conflict of interest.

\section{References}

1. World Health Organization. The Optimal Duration of Exclusive Breastfeeding: Report of an Expert Consultation; World Health Organization: Geneva, Switzerland, 2001. Available online: https:/www.who.int/topics/ breastfeeding/en/.WHO/NHD/01.09,WHO/FCH/CAH/01.24 (accessed on 28 March 2001).

2. American Academy of Paediatrics (AAP). Breastfeeding and the use of human milk section on breastfeeding. Pediatrics 2012, 129, 827-841. [CrossRef] [PubMed]

3. Agostoni, C.; Braegger, C.; Decsi, T.; Kolacek, S.; Koletzko, B.; Michaelsen, K.F.; Mihatsch, W.; Moreno, L.A.; Puntis, J.; Shamir, R.; et al. Breast-feeding: A commentary by the Espghan committee on nutrition. J. Pediatric Gastroenterol. Nutr. 2009, 49, 112-125. [CrossRef] [PubMed]

4. World Health Organization; United Nations Children's Fund (UNICEF). Global Breastfeeding Scorecard, 2019: Increasing Commitment to Breastfeeding through Funding and Improved Policies and Programmes; World Health Organization: Geneva, Switzerland, 2019. Available online: https://apps.who.int/iris/handle/10665/326049 (accessed on 15 July 2019).

5. United Nations Children's Fund (UNICEF). Breastfeeding: A Mother's Gift, for Every Child; United Nations Children's Fund (UNICEF): New York, NY, USA, 2018.

6. Ballard, O.; Morrow, A.L. Human milk composition: Nutrients and bioactive factors. Pediatric Clin. N. Am. 2013, 60, 49-74. [CrossRef]

7. Andreas, N.J.; Kampmann, B.; Mehring Le-Doare, K. Early human breast milk: A review on its composition and bioactivity. Hum. Dev. 2015, 91, 629-635. [CrossRef]

8. Walker, A. Breast milk as a gold standard for protective nutrients. J. Pediatric 2010, 156, 3-7. [CrossRef] [PubMed]

9. Hurley, W.L.; Theil, P.K. Perspectives on immunoglobulins in colostrum and milk. Nutrients 2011, 3, $442-474$. [CrossRef]

10. Goldman, A.S. Modulation of the gastrointestinal tract of infants by human milk. Interfaces and interactions. An evolutionary perspective. J. Nutr. 2000, 130, 426-431. [CrossRef]

11. Zdrojewicz, Z.; Herman, M.; Sałamacha, M.; Starostecka, E. Ludzkie mleko-fakty i mity. Pediatric Med. Rodz. 2017, 13, 11-20. [CrossRef]

12. Kulski, J.K.; Hartmann, P.E. Changes in human milk composition during the initiation of lactation. Aust. J. Exp. Biol. Med. Sci. 1981, 59, 101-114. [CrossRef]

13. Bravi, F.; Wiens, F.; Decarli, A.; Dal Pont, A.; Agostoni, C.; Ferraroni, M. Impact of maternal nutrition on breast-milk composition: A systematic review. Am. J. Clin. Nutr. 2016, 104, 646-662. [CrossRef]

14. Bzikowska-Jura, A.; Czerwonogrodzka-Senczyna, A.; Olędzka, G.; Szostak-Węgierek, D.; Weker, H.; Wesołowska, A. Maternal nutrition and body composition during breastfeeding: Association with human milk composition. Nutrients 2018, 10, 1379. [CrossRef] [PubMed] 
15. Hoppu, U.; Isolauri, E.; Laakso, P.; Matomāki, J.; Laitinen, K. Probiotics and dietarycounselling targeting maternal dietary fat intake modifies breast milk fattyacids and cytokines. Eur. J. Nutr. 2012, 51, 211-219. [CrossRef] [PubMed]

16. Pusceddu, M.M.; El Aidy, S.; Crispie, F.; O'Sullivan, O.; Cotter, P.; Stanton, C.; Kelly, P.; Cryan, J.F.; Dinan, T.G. Correction: N-3 Polyunsaturated Fatty Acids (PUFAs) reverse the impact of early-life stress on the gut microbiota. PLoS ONE 2015, 10, e0142228. [CrossRef] [PubMed]

17. Fernández, L.; Langa, S.; Martín, V.; Maldonado, A.; Jiménez, E.; Martín, R.; Rodríguez, J.M. The human milk microbiota: Origin and potential roles in health and disease. Pharmacol. Res. 2013, 69, 1-10. [CrossRef]

18. Donnet-Hughes, A.; Perez, P.F.; Doré, J.; Leclerc, M.; Levenez, F.; Benyacoub, J.; Serrant, P.; Roggero, I.; Schiffrin, E.J. Potential role of the intestinal microbiota of the mother in neonatal immune education. Proc. Nutr. Soc. 2010, 69, 407-415. [CrossRef]

19. LaTuga, M.; Stuebe, A.; Seed, P. A review of the source and function of microbiota in breast milk. Semin. Reprod. Med. 2014, 32, 68-73. [CrossRef]

20. Kotlińska, A.; Huras, H.; Źródła i rola mikrobioty mleka kobiecego. Przegląd literatury przedmiotu. Zdr. Publiczne Zarzadzanie 2017, 15, 178-180. [CrossRef]

21. Navarro-Tapia, E.; Sebastini, G.; Sailer, S.; Toledano, L.A.; Serra-Delgado, M.; Garcia-Algar, Ó.; Andreu-Fernández, V. Probiotic supplementation during the perinatal and infant period: Effects on gut dysbiosis and disease. Nutrients 2020, 12, 2243. [CrossRef]

22. Zijlmans, M.A.; Korpela, K.; Riksen-Walraven, J.M.; de Vos, W.M.; de Weerth, C. Maternal prenatal stress is associated with the infant intestinal microbiota. Psychoneuroendocrinology 2015, 53, 233-245. [CrossRef]

23. Hu, J.; Nomura, Y.; Bashir, A.; Fernandez-Hernandez, H.; Itzkowitz, S.; Pei, Z.; Stone, J.; Loudon, H.; Peter, I. Diversified microbiota of meconium is affected by maternal diabetes status. PLoS ONE 2013, 8, e78257. [CrossRef]

24. Palmer, C.; Bik, E.M.; DiGiulio, D.B.; Relman, D.A.; Brown, P.O. Development of the human infant intestinal microbiota. PLoS Biol. 2007, 5, 1556-1573. [CrossRef] [PubMed]

25. Martín, R.; Heilig, G.; Zoetendal, E.; Smidt, H.; Rodríguez, J. Diversity of the Lactobacillus group in breast milk and vagina of healthy women and potential role in the colonization of the infant gut. J. Appl. Microbiol. 2007, 103, 2638-2644. [CrossRef] [PubMed]

26. Martín, R.; Langa, S.; Reviriego, C.; Jimínez, E.; Marín, M.; Xaus, J.; Fernández, L.; Rodríguez, J. Human milk is a source of lactic acid bacteria for the infant gut. J. Pediatric 2003, 143, 754-758. [CrossRef] [PubMed]

27. Lyons, K.E.; Ryan, C.A.; Dempsey, E.M.; Ross, R.P.; Stanton, C. Breast milk, a source of beneficial microbes and associated benefits for infant health. Nutrients 2020, 12, 1039. [CrossRef]

28. Rodríguez, J.M. The origin of human milk bacteria: Is there a bacterial entero-mammary pathway during late pregnancy and lactation? Adv. Nutr. 2014, 5, 779-784. [CrossRef]

29. Sakwinska, O.; Moine, D.; Delley, M.; Combremont, S.; Rezzonico, E.; Descombe, sP.; Vinyes-Pares, G.; Zhang, Y.; Wang, P.; Thakkar, S.K. Microbiota In Brest milk of Chinese lactating mothers. PLoS ONE 2016, 11, e0160856. [CrossRef]

30. Wold, A.E.; Adlerberth, I. Breast feeding and the intestinal microflora of the infant-Implications for protection against infectious diseases. Adv. Exp. Med. Biol. 2000, 478, 77-93. [CrossRef]

31. Rodríguez, J.; Murphy, K.; Stanton, C.; Ross, R.; Kober, O.; Juge, N.; Avershina, E.; Rudi, K.; Narbad, A.; Jenmalm, M.; et al. The composition of the gut microbiota throughout life, with an emphasis on early life. Microb. Ecol. Health Dis. 2015, 26, 1-17. [CrossRef]

32. Toscano, M.; De Grandi, R.; Grossi, E.; Drago, L. Role of the Human Breast Milk-Associated Microbiota on the Newborns' Immune System: A Mini Review. Front. Microbiol. 2017, 8, 2100. [CrossRef]

33. Grönlund, M.; Arvilommi, H.; Kero, P.; Lehtonen, O.; Isolauri, E. Importance of intestinal colonisation in the maturation of humoral immunity in early infancy: A prospective follow up study of healthy infants aged 0-6 months. Arch. Dis. Child. Fetal Neonatal Ed. 2000, 83, 186-192. [CrossRef]

34. Nawrocka, M.; Szulińska, M.; Bogdański, P. The role of the gut microbiota in the pathogenesis and treatment of obesity and metabolic syndrome. Forum Zaburzeń Metab. 2015, 6, 95-102.

35. Olivares, M.; Díaz-Ropero, M.; Martín, R.; Rodríguez, J.; Xaus, J. Antimicrobial potential of four Lactobacillus strains isolated from breast milk. J. Appl. Microbiol. 2006, 101, 72-79. [CrossRef] [PubMed]

36. Isolauri, E.; Kirjavainen, P.V.; Salminen, S. Probiotics: A role in the treatment of intestinal infection and inflammation? Gut 2002, 50, 54-59. [CrossRef] [PubMed] 
37. Heikkilä, M.; Saris, P. Inhibition of Staphylococcus aureus by the commensal bacteria of human milk. J. Appl. Microbiol. 2003, 95, 471-478. [CrossRef] [PubMed]

38. Beasley, S.S.; Saris, P.E.J. Nisin-producing Lactococcus lactis trains isolated from human milk. Appl. Environ. Microbiol. 2004, 70, 5051-5053. [CrossRef]

39. Barticka, A.; Gałęcka, M.; Mazela, J. The impact of perinatal and postnatal factors on composition of the intestinal microbiota in infants. Stand. Med. Pediatric 2016, 13, 165-17234.

40. Palmeira, P.; Carneiro-Sampaio, M. Immunology of breast milk. Rev. Assoc. Med. Bras. 2016, 62, $584-593$. [CrossRef]

41. Orczyk-Pawiłowicz, M.; Wesołowska, A. The differences in the biochemical composition of the milk of mothers of premature and term infants-nutritional and therapeutic aspects. Stand. Med. Pediatric 2013, 10, 677-686.

42. Cacho, N.T.; Harrison, N.A.; Parker, L.A.; Padgett, K.A.; Lemas, D.J.; Marcial, G.E.; Li, N.; Carr, L.E.; Neu, J.; Lorca, G.L. Personalization of the microbiota of donor human milk with mother's own milk. Front. Microbiol. 2017, 8, 1-12. [CrossRef]

43. Kunz, C.; Rudloff, S. Potential anti-inflammatory and anti-infectious effects of human milk oligosaccharides. Adv. Exp. Med. Biol. 2008, 606, 455-465. [CrossRef]

44. Marcobal, A.; Barboza, M.; Sonnenburg, E.D.; Pudlo, N.; Martens, E.C.; Desai, P.; Lebrilla, C.B.; Weimer, B.C.; Mills, D.A.; German, J.B.; et al. Bacteroides in the infant gut consume milk oligosaccharides via mucusutilization pathways. Cell Host Microbe 2011, 10, 507-514. [CrossRef] [PubMed]

45. Boehm, G.; Stahl, B. Oligosaccharides from milk. J. Nutr. 2007, 137, 847-849. [CrossRef] [PubMed]

46. Kuntz, S.; Rudloff, S.; Kunz, C. Oligosaccharides from human milk influence growth-related characteristics of intestinally transformed and nontransformed intestinal cells. Br. J. Nutr. 2008, 99, 462-471. [CrossRef] [PubMed]

47. Bode, L. The functional biology of human milk oligosaccharides. Early Hum. Dev. 2015, 91, 619-622. [CrossRef] [PubMed]

48. Urbaniak, C.; Angelini, M.; Gloor, G.B.; Reid, G. Human milk microbiota profiles in relationto birthing method, gestation and infant gender. Microbiome 2016, 4. [CrossRef]

49. Cabrera-Rubio, R.; Collado, M.C.; Laitinen, K.; Salminen, S.; Isolauri, E.; Mira, A. The human milk microbiome changes over lactation and is shaped by maternal weight and mode of delivery. Am. J. Clin. Nutr. 2012, 96, 544-551. [CrossRef]

50. Reven, P.; Mrak, V.; Matijašić, B.B.; Horvat, S.; Rogelj, I. Administration of probiotics Lactobacillus rhamnosus GG and Lactobacillus gasseri K7 during pregnancy and lactation changes mouse mesenteric lymph nodes and mammary gland microbiota. J. Dairy Sci. 2015, 98, 2114-2128. [CrossRef]

51. Bezirtzoglou, E.; Tsiotsias, A.; Welling, G.W. Microbiota profile in feces of breast- and formula-fed newborns by using fluorescence in situ hybridization (FISH). Anaerobe 2011, 17, 478-482. [CrossRef]

52. Favier, C.F.; Vaughan, E.E.; de Vos, W.M.; Akkermans, A.D.L. Molecular monitoring of succession of bacterial communities in human neonates. Appl. Environ. Microbiol. 2002, 68, 219-226. [CrossRef]

53. Cerdó, T.; Ruíz, A.; Suárez, A.; Campoy, C. Probiotic, Prebiotic and Brain Development. Nutrients 2017, 9, 1247. [CrossRef]

54. Satokari, R.; Gronroos, T.; Laitinen, K.; Salminen, S.; Isolauri, E. Bifidobacterium and Lactobacillus DNA in the human placenta. Lett. Appl. Microbiol. 2009, 48, 8-12. [CrossRef] [PubMed]

55. Jimenez, E.; Fernandez, L.; Marin, M.L.; Martín, R.; Odriozola, J.M.; Nueno-Palop, C.; Narbad, A.; Olivares, M.; Xaus, J.; Rodríguez, J.M. Isolation of commensal bacteria from umbilical cord blood of healthy neonates born by cesarean section. Curr. Microbiol. 2005, 51, 270-274. [CrossRef] [PubMed]

56. Nuriel-Ohayon, M.; Neuman, H.; Koren, O. Microbial changes during pregnancy, birth, and infancy. Front. Microbiol. 2016, 7, 1031. [CrossRef] [PubMed]

57. Dominguez-Bello, M.G.; De Jesus-Laboy, K.M.; Shen, N.; Cox, L.M.; Amir, A.; Gonzalez, A.; Bokulich, N.A.; Song, S.J.; Hoashi, M.; Rivera-Vina, J.I.; et al. Partial restoration of the microbiota of cesarean-born infants via vaginal microbial transfer. Nat. Med. 2016, 22, 250-253. [CrossRef] [PubMed]

58. Rinne, M.M.; Gueimonde, M.; Kalliomaki, M.; Hoppu, U.; Salminen, S.J.; Isolauri, E. Similar bifidogenic effects of prebiotic-supplemented partially hydrolyzed infant formula and breastfeeding on infant gut microbiota. FEMS Immunol. Med. Microbiol. 2005, 43, 59-65. [CrossRef] [PubMed] 
59. Rautava, S. Early microbial contact, the breast milk microbiome and child health. J. Dev. Orig. Health Dis. 2016, 7, 5-14. [CrossRef]

60. Baldassarre, M.E.; Di Mauro, A.; Mastromarino, P.; Fanelli, M.; Martinelli, D.; Urbano, F.; Capobianco, D.; Laforgia, N. Administration of a multi-strain probiotic product to women in the perinatal period differentially affects the breast milk cytokine profile and may have beneficial effects on neonatal gastrointestinal functional symptoms. A randomized clinical trial. Nutrients 2016, 8, 677. [CrossRef]

61. Mastromarino, P.; Capobianco, D.; Miccheli, A.; Pratico, G.; Campagna, G.; Laforgia, N.; Capursi, T.; Baldassarre, M.E. Administration of a multistrain probiotic product (VSL\#3) to women in the perinatal period differentially affects breast milk beneficial microbiota in relation to mode of delivery. Pharmacol. Res. 2015, 95-96, 63-70.

62. Abrahamsson, T.R.; Sinkiewicz, G.; Jakobsson, T.; Fredrikson, M.; Björkstén, B. Probiotic lactobacilli in breast milk and infant stool in relation to oral intake during the first year of life. J. Pediatric Gastroenterol. Nutr. 2009, 49, 349-354. [CrossRef]

63. Perez, P.F.; Dore, J.; Leclerc, M.; Levenez, F.; Benyacoub, J.; Serrant, P.; Segura-Roggero, I.; Schiffrin, E.J.; Donnet-Hughes, A. Bacterial imprinting of the neonatal immune system: Lessons from maternal cells? Pediatrics 2007, 119, 724-732. [CrossRef]

64. Rescigno, M.; Urbano, M.; Valzasina, B.; Francolín, M.; Rotta, G.; Bonasio, R.; Granucci, F.; Kraehenbuhl, J.; Ricciardi-Castagnoli, P. Dendritic cells express tight junction proteins and penetrate gut epithelial monolayers to sample bacteria. Nat. Immunol. 2001, 2, 361-367. [CrossRef] [PubMed]

65. Rescigno, M.; Rotta, G.; Valzasina, B.; Ricciardi-Castagnoli, P. Dendritic cells shuttle microbes across gut epithelial monolayers. Immunobiology 2001, 204, 572-581. [CrossRef] [PubMed]

66. Bearfield, C.; Davenport, E.S.; Sivapathasundaram, V.; Allaker, R.P. Possible association between amniotic fluid micro-organism infection and microflora in the mouth. Br. J. Obstet. Gynaecol. 2002, 109, 527-533. [CrossRef] [PubMed]

67. Pannaraj, P.S.; Li, F.; Cerini, C.; Bender, J.M.; Yang, S.; Rollie, A.; Adisetiyo, H.; Zabih, S.; Lincez, P.J.; Bittinger, K.; et al. Association between breast milk bacterial communities and establishment and development of the infant gut microbiome. JAMA Pediatric 2017, 171, 647-654. [CrossRef]

68. Mackie, R.I.; Sghir, A.; Gaskins, H.R. Developmental microbial ecology of the neonatal gastrointestinal tract. Am. J. Clin. Nutr. 1999, 69, 1035-1045. [CrossRef] [PubMed]

69. Moossavi, S.; Sepehri, S.; Robertson, B.; Bode, L.; Goruk, S.; Field, C.J.; Lix, L.M.; de Souza, R.J.; Becker, A.B.; Mandhane, P.J.; et al. Composition and variation of the human milk microbiota are influenced by maternal and early-life factors. Cell Host Microbe 2019, 25, 324-335. [CrossRef]

70. Azad, M. Infant feeding and the developmental origins of chronic disease in the CHILD Cohort: Role of human milk bioactives and gut microbiota. Breastfeed. Med. 2019. [CrossRef]

71. Stanislawski, M.; Dabelea, D.; Wagner, B.D.; Iszatt, N.; Dahi, C.; Sontag, M.K.; Knight, N.; Lozupone, C.A.; Eggesbø, M. Gut microbiota in the first 2 years of life and the association with body mass index at age 12 in a norwegian birth cohort. Am. Soc. Microbiol. 2018. [CrossRef]

72. Jurkowski, M.; Błaszczyk, M. Charakterystyka fizjologiczno-biochemiczna bakterii fermentacji mlekowej. Kosm. Probl. Nauk Biol. 2012, 3, 493-504.

73. Jost, T.; Lacroix, C.; Braegger, C.; Chassard, C. Assessment of bacterial diversity in breast milk using culture-dependent and culture-independent approaches. Br. J. Nutr. 2013, 14, 1-10. [CrossRef]

74. Sinkiewicz, G.; Ljunggren, L. Occurrence of Lactobacillus reuteri in human breast milk. Microb. Ecol. Health Dis. 2008, 20, 122-126. [CrossRef]

75. Soto, A.; Martín, V.; Jiménez, E.; Mader, I.; Rodríguez, J.M.; Fernández, L. Lactobacilli and bifidobacteria in human breast milk: Influence of antibiotherapy and other host and clinical factors. J. Pediatric Gastroenterol. Nutr. 2014, 59. [CrossRef] [PubMed]

76. Matsumiva, Y.; Kato, N.; Watanabe, K.; Kato, H. Molecular epidemiological study of vertical transmission of vaginal Lactobacillus species from mothers to newborn infants in Japanese, by arbitrarily primed polymerase chain reaction. J. Infect. Chemother. 2002, 8, 43-49. [CrossRef] [PubMed]

77. Ahrné, S.; Lönnermark, E.; Wold, A.E.; Aberg, N.; Hesselmar, B.; Saalman, R.; Strannegard, I.L.; Molin, G.; Adlerberth, I. Lactobacilli in the intestinal microbiota of Swedishinfants. Microbes Infect. 2005, 7, 1256-1262. [CrossRef] [PubMed] 
78. Martín, V.; Maldonado-Barragán, A.; Moles, L.; Rodriguez-Baños, M.; Campo, R.D.; Fernández, L.; Rodríguez, J.M.; Jiménez, E. Sharing of bacterial strains between breast milk and infant feces. J. Human Lact. Off. J. Int. Lact. Consult. Assoc. 2012, 28, 36-44. [CrossRef] [PubMed]

79. Ma, J.; Li, Z.; Zhang, W.; Zhang, C.; Zhang, Y.; Mei, H.; Zhou, N.; Wang, H.; Wang, L.; Wu, D. Comparison of gut microbiota in exclusively breast-fed and formula-fed babies: A study of 91 term infants. Sci. Rep. 2020, 10, 15792. [CrossRef] [PubMed]

80. Urbańska, M.; Szajewska, H. The efficacy of Lactobacillus reuteri DSM 17938 in infants and children: A review of the current evidence. Eur. J. Pediatrics 2014, 173, 1327-1337. [CrossRef]

81. Hatakka, K.; Savilahti, E.; Ponka, A.; Meurman, J.H.; Poussa, T.; Näse, L.; Saxelin, M.; Korpela, R. Effect of long term consumption of probiotic milk on infections in children attending day care centers: Double blind, randomised trial. BMJ 2001, 322, 1327. [CrossRef]

82. Martín, R.; Jiménez, E.; Olivares, M.; Marín, M.L.; Fernández, L.; Xaus, J.; Rodríguez, J.M. Lactobacillus salivarius CECT 5713, a potential probiotic strain isolated from infant feces and breast milk of a mother-child pair. Int. J. Food Microbiol. 2006, 112, 35-43. [CrossRef]

83. Martín, R.; Olivares, M.; Marín, M.L.; Fernández, L.; Xaus, J.; Rodríguez, J.M. Probiotic potential of 3 lactobacilli strains isolated from breast milk. J. Hum. Lact. 2005, 21, 8-17. [CrossRef]

84. Jiménez, E.; Fernández, L.; Maldonado, A.; Martín, R.; Olivares, M.; Xaus, J.; Rodríguez, J.M. Oral administration of Lactobacillus strains isolated from breast milk as an alternative for the treatment of infectious mastitis during lactation. Appl. Environ. Microbiol. 2008, 74, 4650-4655. [CrossRef]

85. Arroyo, R.; Martín, V.; Maldonado, A.; Jiménez, E.; Fernández, L.; Rodríguez, J.M. Treatment of infectious mastitis during lactation: Antibiotics versus oral administration of lactobacilli isolated from breast milk. Clin. Infect. Dis. 2010, 50, 1551-1558. [CrossRef] [PubMed]

86. Gregora, M. Lactobacillus species in breast milk, probiotics-current knowledge and future prospects, shymaa enany. IntechOpen 2018. [CrossRef]

87. Díaz-Ropero, M.; Martín, R.; Sierra, S.; Lara-Villoslad, F.; Rodríguez, J.; Xaus, J.; Olivares, M. Two Lactobacillus strains, isolated from breast milk, differently modulate the immune response. J. Appl. Microbiol. 2007, 102, 337-343. [CrossRef]

88. Gomez-Gallego, C.; Garcia-Mantrana, I.; Salminen, S.; Collado, M.C. The human milk microbiome and factors influencing its composition and activity. Semin. Fetal Neonatal Med. 2016, 21, 400-405. [CrossRef] [PubMed]

89. Cabrera-Rubio, R.; Mira-Pascual, L.; Mira, A.; Collado, M.C. Impact of mode of delivery on the milk microbiota composition of healthy women. J. Dev. Orig. Health Dis. 2016, 7, 54-60. [CrossRef]

90. Grönlund, M.M.; Gueimonde, M.; Laitinen, K.; Kociubinski, G.; Grönroos, T.; Salminen, S.; Isolauri, E. Maternal breast-milk and intestinal bifidobacteria guide the compositional development of the Bifidobacterium microbiota in infants at risk of allergic disease. Clin. Exp. Allergy 2007, 37, 1764-1772. [CrossRef] [PubMed]

91. Jiménez, E.; de Andrés, J.; Manrique, M.; Pareja-Tobes, P.; Tobes, R.; Martínez-Blanch, J.F.; Codoñer, F.M.; Ramón, D.; Fernández, L.; Rodríguez, J.M. Metagenomic analysis of milk of healthy and mastitis-suffering women. J. Hum. Lact. 2015, 31, 406-415. [CrossRef]

92. Olivares, M.; Albrecht, S.; de Palma, G.; Ferrer, M.D.; Castillejo, G.; Schols, H.A.; Sanz, Y. Human milk composition differs in healthy mothers and mothers with celiac disease. Eur. J. Nutr. 2015, 54, 119-128.

93. González, R.; Maldonado, A.; Martín, V.; Mandomando, I.; Fumadó, V.; Metzner, K.J.; Sacoor, C.; Fernández, L.; Macete, E.; Alonso, P.L.; et al. Breast milk and gut microbiota in African mothers and infants from an area of high HIV prevalence. PLoS ONE 2013, 8, e80299. [CrossRef]

94. Collado, M.C.; Laitinen, K.; Salminen, S.; Isolauri, E. Maternal weight and excessive weight gain during pregnancy modify the immunomodulatory potential of breast milk. Pediatric Res. 2012, 72, 77-85. [CrossRef] [PubMed]

Publisher's Note: MDPI stays neutral with regard to jurisdictional claims in published maps and institutional affiliations. 